\title{
Reservoir response to a well test identified through a self-potential monitoring at the Mataloko geothermal field, central Flores, Indonesia
}

\author{
Kasumi YasuKAWA ${ }^{1}$, Enar KusdinaR ${ }^{2}$ and Hirofumi MURAOKA ${ }^{1}$
}

\begin{abstract}
Kasumi Yasukawa, Enar Kusdinar and Hirofumi Muraoka (2002) Reservoir response to a well test identified through a self-potential monitoring at the Mataloko geothermal field, central Flores, Indonesia. Bull. Geol. Surv. Japan, vol. 53 (2/3), p. 355-363, 8 figs.
\end{abstract}

\begin{abstract}
Self-potential (SP) monitoring was carried out at Mataloko, Flores Island, Nusa Tenggara, Indonesia to detect electric potential changes at the reservoir caused by well operations. Surface SP distribution was monitored around the well during flow tests. To solve the problem about a base point of SP, a concept of relative SP was introduced assuming that the average SP among the monitoring points is always zero. As a result, a clear change of the relative SP corresponding to the reservoir condition was observed. Thus relative SP monitoring can be applied to grasp the extent of a reservoir and the change of its hydrological conditions.
\end{abstract}

\section{Introduction}

The SP surveys have been widely conducted for geothermal field exploration assuming that the main cause of the SP anomaly is streaming potential. Theoretically continuous SP observations can be applied for reservoir monitoring. However, practical procedures for the interpretation of continuous SP data have not been constructed yet although some attempts of continuous SP monitoring have been made recently (e.g. Yasukawa et al., 2001, Yokoi et al., 2001).

One of the difficulties in the interpretation of continuous SP monitoring data is that there are many causes which perturb the surface SP such as artificial noises, magnetic field variations of external origin, rainfall effect and other sources so that it is difficult to identify the SP change caused by the subsurface fluid flow. Another problem is that it is almost impossible to find an ideal reference point in the real field where the electric potential is sufficiently stable that the SP at each monitoring point can be plotted in comparison to this point. Establishing a proper base point has always been an obstacle for SP monitoring.

This paper presents the result of SP monitoring at the Mataloko geothermal prospect, Flores, Indonesia where a flowtest of an exploration well MT-2 was conducted in 2001 as a part of the Japan-

\footnotetext{
${ }^{1}$ Institute for Geo-Resources and Environment, GSJ

${ }^{2}$ Directorate of Volcanology and Geological Hazard Mitigation, Jl. Diponegoro No.57, Bandung, 40122 Indonesia
}

Indonesia cooperative research project, "The Exploration of Small-scale Geothermal Resources in the Eastern Part of Indonesia," conducted by the Geological Survey of Japan, New Energy and Industrial Technology Development Organization and Volcanological Survey of Indonesia. The SP at eight surface monitoring points around the well near the main geothermal manifestation area were monitored during and after a flowtest in January. As a result, drastic SP changes during a pressure build-up of the well were observed at all monitoring points. Therefore for a flow-test in July, eight more monitoring points are added to identify the extent of the SP changes.

To resolve the difficulty to find a stable reference point for SP measurement, the idea of relative SP was introduced for the analysis of the data. Assuming that the average of SP values from all monitoring points is zero at each moment, the "relative SP" at each point was calculated by referring to the average SP. The effectiveness of relative SP monitoring is discussed in this paper.

\section{SP monitoring at the Mataloko geothermal prospect}

2.1 SP survey and monitoring in Mataloko

The Mataloko geothermal field is located about 10 $\mathrm{km}$ southeast of Bajawa town, in the central part of Flores Island, Nusa Tenggara, Indonesia (Fig. 1). Active volcanoes Inerie and Inelika exist south and north of Mataloko, respectively. The basin between

Keywords: geothermal reservoir, self-potential, monitoring, well-test, Indonesia 


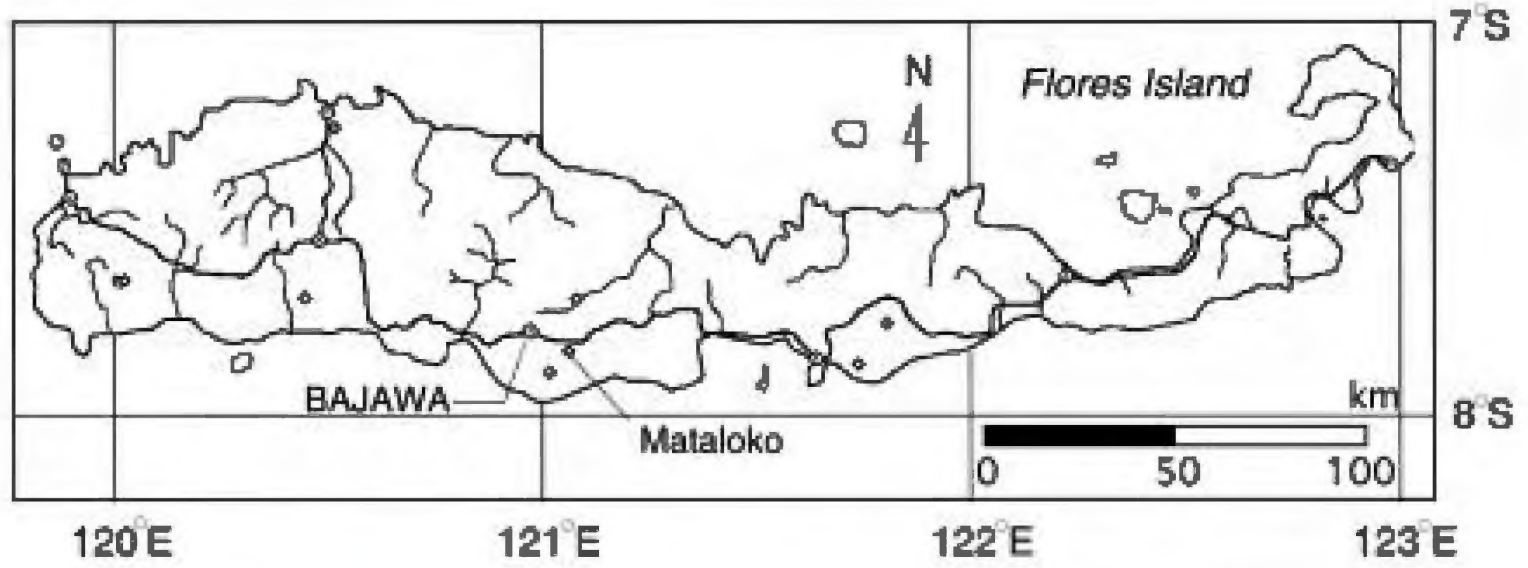

Fig. 1 Location of the Mataloko geothermal field.

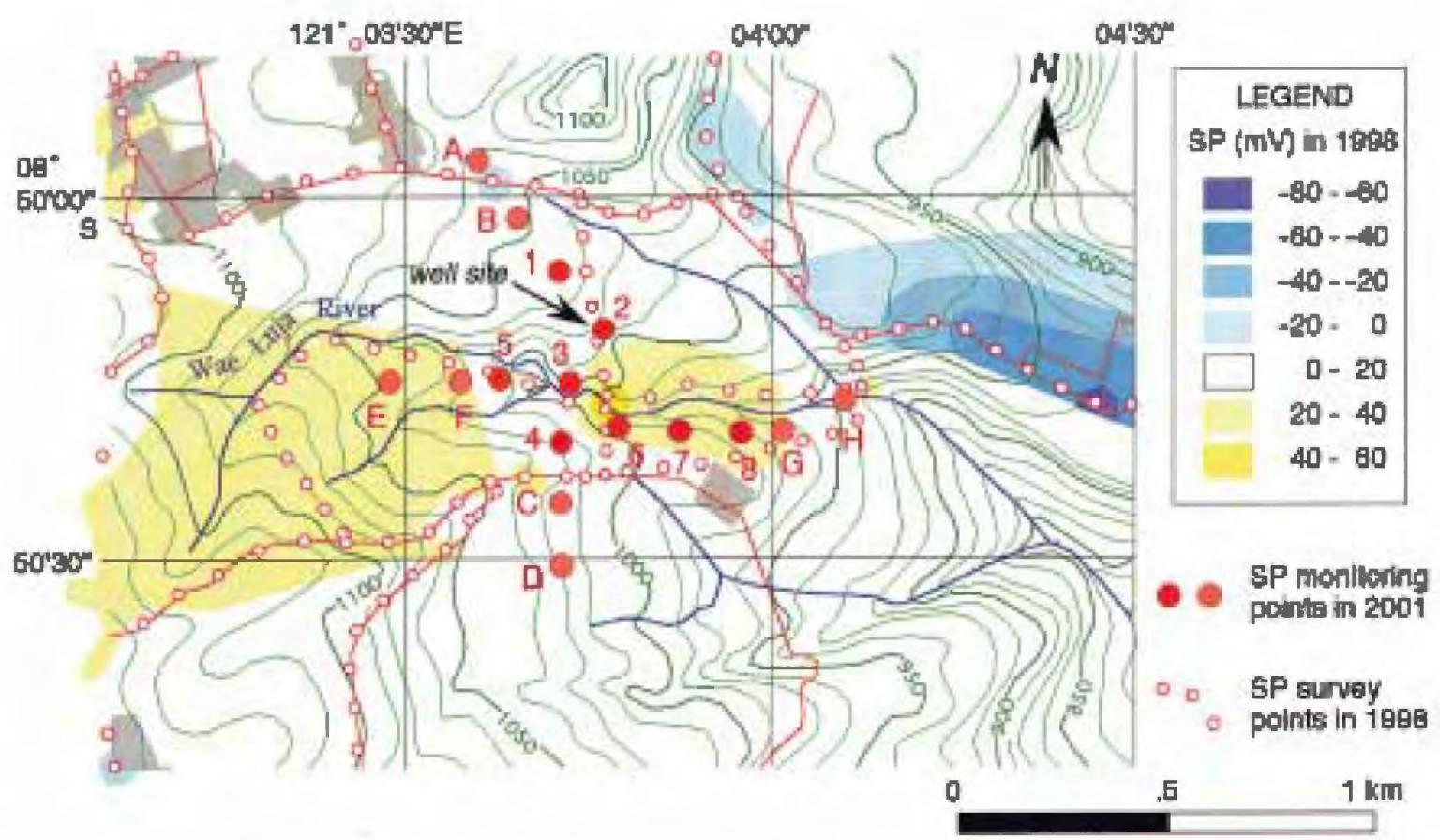

Fig. 2 SP monitoring points at the Mataloko area.

these two volcanoes has a length of $10 \mathrm{~km}$ in the NNW-SSE direction with a width of $4 \mathrm{~km}$. The older volcanoes exist only at the edge of this basin while younger volcanoes widely exist in the inner part. Therefore this basin is considered a caldera (Muraoka et al., 2000).

Surface manifestations of geothermal steam and hot springs are observed at the Mataloko area. The principal manifestation area, at an elevation of around $1000 \mathrm{~m}$, is located at a valley along the river named Wae Luja running eastward. Some alteration zones are also seen around this river. This zone is identified as a low resistivity zone according to Andan et al. (1997).

A SP survey was widely done at Mataloko in 1998 (Yasukawa et al., 2000). The highest SP anomaly in the Mataloko area was observed at the main geothermal manifestation area along the Wae-Luja
River. This positive anomaly is limited only to the vicinity of the stream to the east (Fig. 2). This result is consistent with the fact that there are some hot springs in the east of the manifestation but none have been observed in the west.

The SP monitoring was conducted in January and July, 2001, around the main geothermal area in Mataloko during flow-tests of well MT-2. Although the SP monitoring began two days after the start of production due to the setting problem in January, the monitoring period covers both the start and shut-in of production in July (Fig. 3). Figure 2 shows the location of SP monitoring points. The number of observation points was eight in January (No. 1 to 8 ) and sixteen in July (No. 1 to 8, A to H) with a spacing of about $200 \mathrm{~m}$ along the N-S and EW survey lines. The first eight points were selected around a positive SP anomaly zone that is 


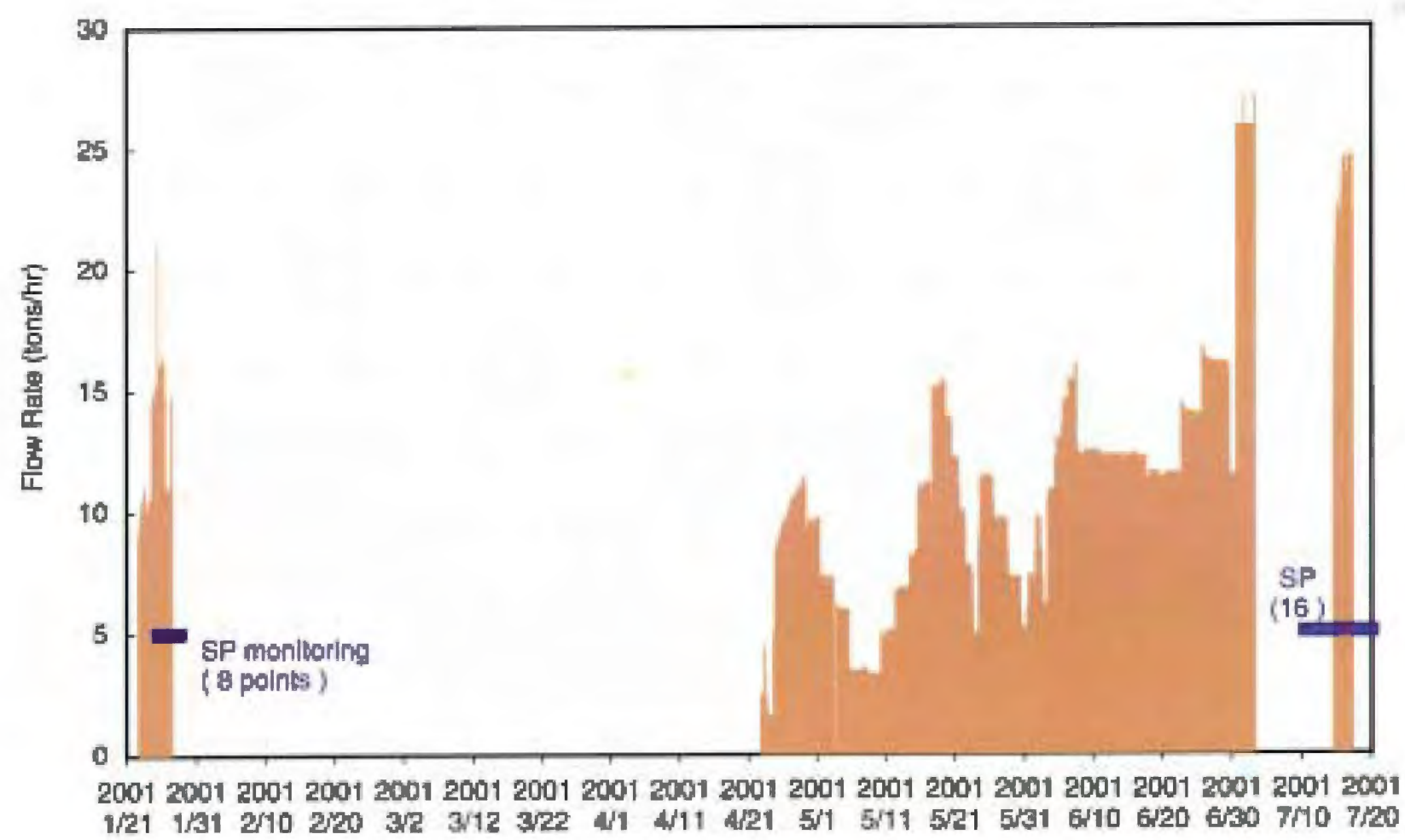

Fig. 3 SP monitoring period in 2001 and flow rate from well MT-2.

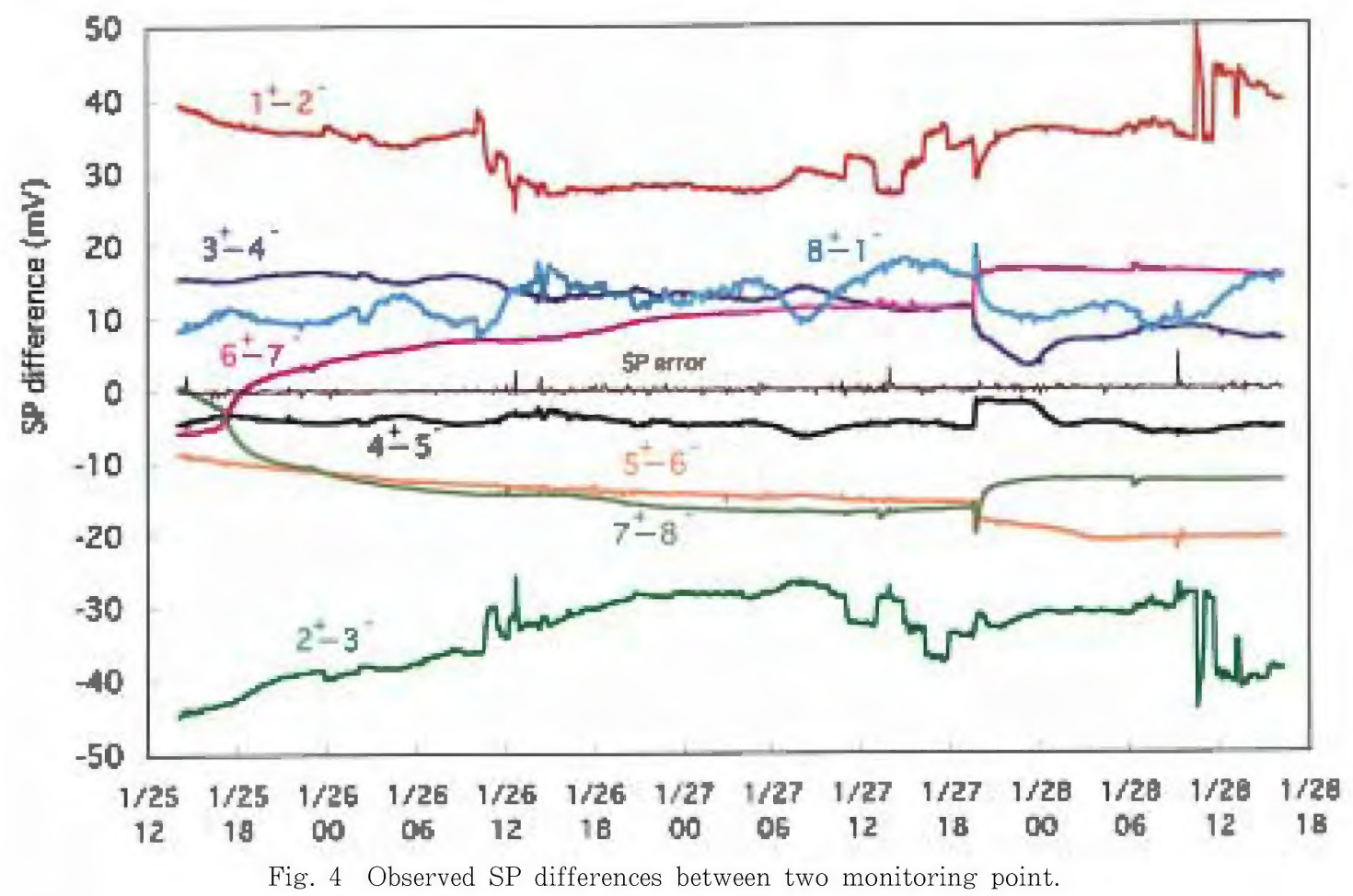

considered to be a fluid discharge zone (Yasukawa et al., 1998). Since clear SP responses of the well operations were observed at all eight points in January, an additional eight points were selected in July to cover a wider area with an extension of $1400 \mathrm{~m}$ in the $\mathrm{E}-\mathrm{W}$ and $1200 \mathrm{~m}$ in the N-S directions.

\subsection{Results of SP monitoring at Mataloko in January}

Figure 4 shows the observation results of Mataloko SP monitoring during January 25-28, 2001 with a sampling interval of five minutes. Electric potential differences between two monitoring points have been monitored for eight channels; e.g., No. 1 to No. 2, 

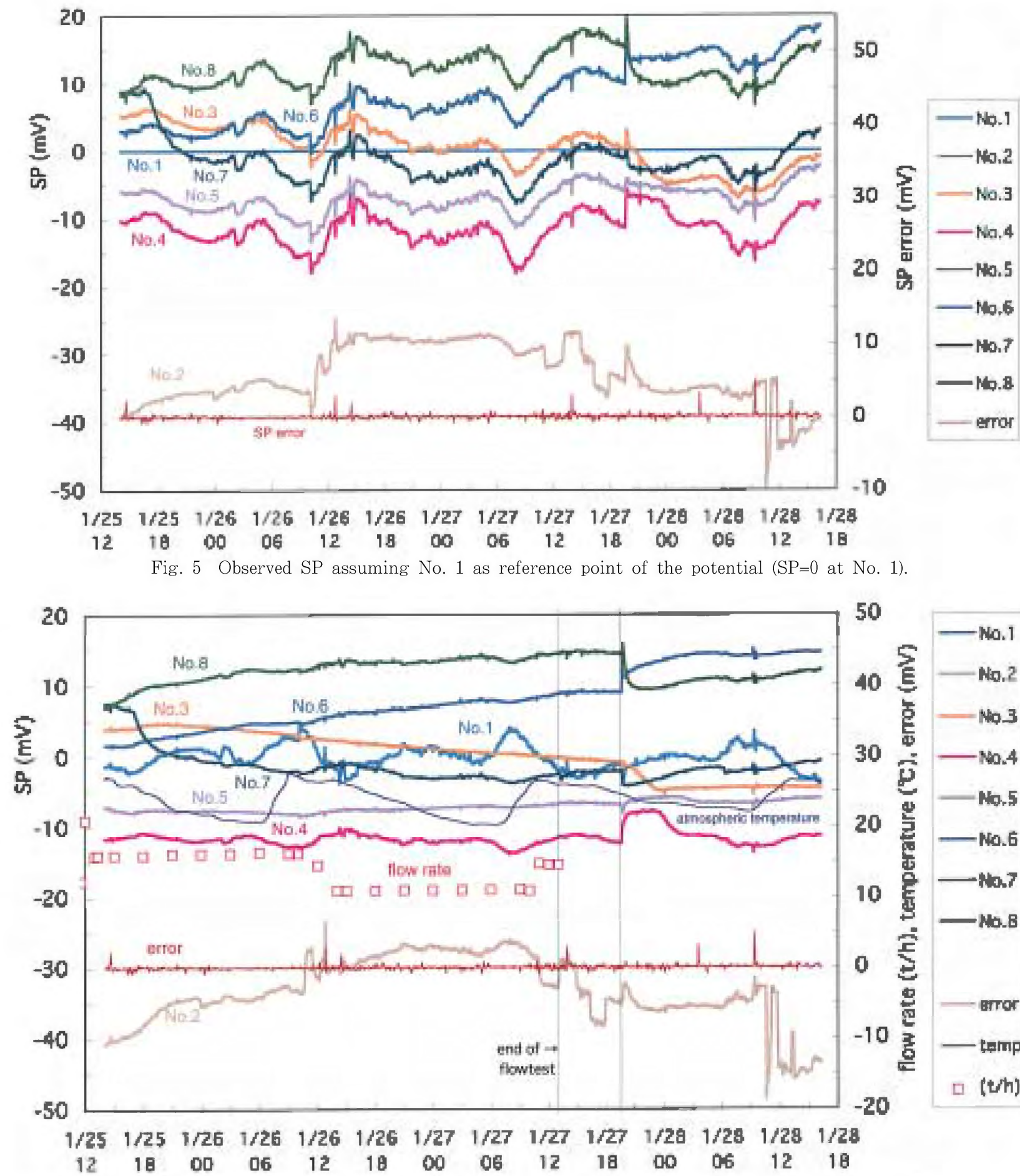

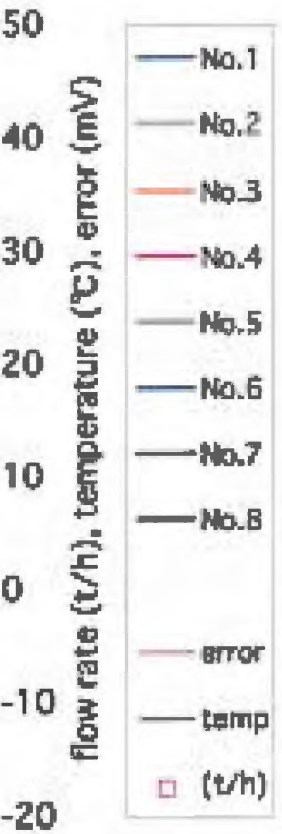

Fig. 6 "Relative" SP variations in January, 2001, assuming average of seven monitoring points (without

No. 2) at each moment is zero.

No. 2 to No. 3 , ......, and No. 8 to No. 1. The summation of all the channels should be zero. However, as seen in Fig. 4, the summation (denoted as "SP errors" in the figure) is not always zero. Since the multiplexer of the data-logger scans each channel with a finite interval, high frequency noises cause non-zero errors on the data.

Figure 5 shows the observed SP assuming No.1 as reference point. As a result, all the curves in Fig. 5 except for No. 2 have similar tendencies in SP variation, and the behavior of each monitoring point is not clearly indicated. It can be interpreted that SP at No.1 itself is affected by local phenomena and quite unstable. For cases with any other monitoring point as a reference point, the same problem occurred.

To avoid the problem of an unstable reference point, the average of the data for all monitoring 
points at each moment was used as a reference value. In this paper, the SP value based on the average is called "relative SP" while conventional SP has a local reference point.

Figure 6 shows the relative SP observed at Mataloko. Note that this figure shows the relative SP based on the average of seven points without No. 2. Since No. 2, which is located approximately fifteen meters from the wellhead of MT-2, is affected by well-casing and has an extremely different behavior from the other points, this point should be eliminated from the average calculation. The characteristic of each monitoring point is quite distinctive in this figure.

In Fig. 6, the production rate from the well is also shown. The SP at No. 2 slowly increases with production, stops increasing after the decrease of flow rate on Janualy 26 th and decreases after shutin on January 27th. A clear negative correspondence between flow rate and SP at No. 2 was also observed on January 27th around noon when there is a step-wise change in flow rate. There is no flow data after 13:00 on January 27th because flow-test was over at this moment. However, the relative SP at No. 2 suggests that the well operation on January 27 th continues till 19:30, and SP at all the other monitoring points show quick responses at this time. At No. 3 and No. 7, changes of the SP trends were also observed after this time. Rapid SP changes at No. 2 around noon on January 26th and 28th are identified. They are caused by wellhead bulb operations of well MT-2.

Though it rained everyday for a few hours in the early afternoon in this period, the effect of the rain on SP was not clearly observed. The SP drifts for the first few hours of the observation are because of the poor contact of the electrodes with the ground.

\subsection{Results of SP monitoring at Mataloko in July}

Since the SP change caused by the shut-in of the well was observed at eight monitoring points in January, a more extensive SP monitoring was planned for the flow-test in July.

Figures 7 and 8 show the observation results of Mataloko SP monitoring during July 11-21, 2001. A short-term flowtest was conducted for three days in this period. Eight more monitoring points (A, B, C, $D, E, F, G$ and $H$ ) were added to the first eight points (No.1 to 8). Locations of these points are shown in Fig. 2. Note that this short-term flowtest was carried out after a three-month long flowtest from April to early July. The reservoir condition is thought to be changed from that in January.

The relative SP change observed for this period is shown in Fig. 7. The upper graph in Fig. 7 shows the results for monitoring points aligned from north to south while the lower graph shows points from west to east. Since there is a lack of earlytime data from No. 6, the relative SP is calculated based on the average of 14 points excluding No. 2 and 6. In Fig. 7, a common high frequency variation is identified for most of the monitoring points. It is considered to be caused by the telluric current induced by external geomagnetic variations. The waveform of "external noise" in Fig. 7 is calculated from the 14 observation data except data for No. 2 and 6 , as the average records the polarities that are adjusted to have the same sense in the change caused by external noise.

Figure 8 is obtained by subtracting the external geomagnetic noise from each curve in Fig. 7. In this calculation, the intensity of the external noise $k$ at each monitoring point is determined to minimize $\sum\left(V_{n+1}-V_{n}\right)^{2}$, where $V_{n}=V_{n}-k \cdot e_{n} ; V_{n}$ is the observed data, $e_{n}$ is the external noise shown in Fig. 7 and subscription $n$ indicates the $n$-th data in a time series.

No clear SP responses to the shut-in of the well were identified in July except for No. 2. The SP at No. 2 decreased both after the start and shut-in of production. Although the changes are quite small, the change in SP trend at the beginning of production was observed at No. 2, No. 3, No. 4, No. 5, C, $\mathrm{E}$ and $\mathrm{F}$, and $\mathrm{SP}$ trend changed when production started and returned to the first trend after the shut-in at No. 8, A, B, D and G. At No. 1, No. 6 and No. 7, no response to the well operation was observed.

The effect of rainfall, which was not detected in January, is clearly identified at all monitoring points in Fig. 8.

\section{Discussions}

The SP responses to the shut-in of the well after a short flowtest in January and in July were quite different. In January a clear sharp SP change after the shut-in occurred at all eight monitoring points while no clear change occurred in July. The main reason for this phenomenon is that the monitoring in January was conducted immediately after the well completion while that in July was after a longterm flowtest. In January, the liquid-phase saturation in the reservoir was quite high and flow of liquid-phase was induced by the production test, resulting in generation of the electric currents and quick SP changes. However in July, a considerably less liquid-phase was remaining in the reservoir so that no detectable streaming potential occurred. This is consistent with the fact that the produced steam in January was white colored while that in July was quite transparent. White steam is considered to contain more liquid than transparent steam. 


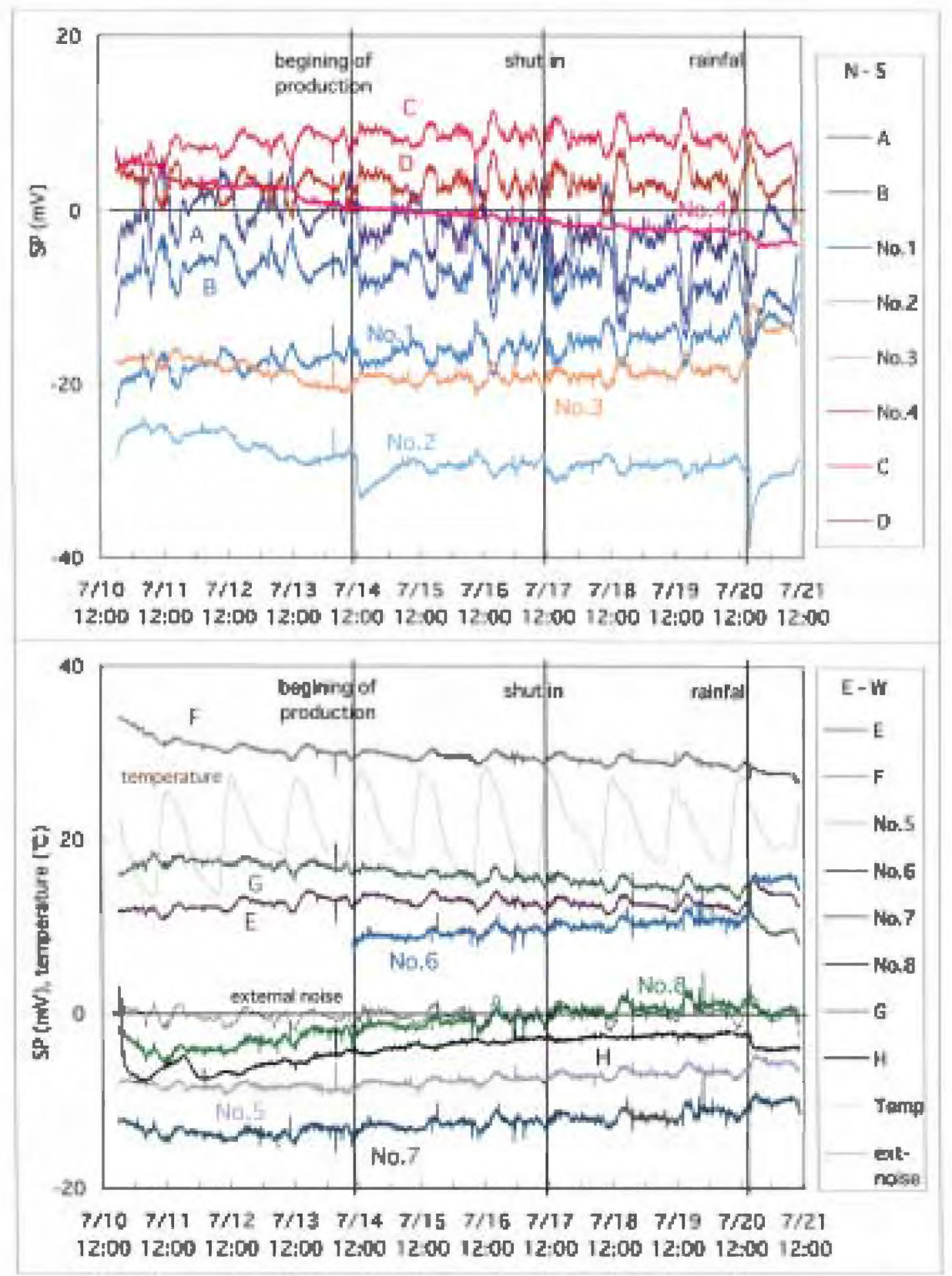

Fig. 7 "Relative" SP variations in July, 2001, based on average of 14 monitoring points (without Nos. 2 and 6).

The SP at No. 2 is significantly lower than the others possibly because of the well casing. The SP near a conductive subsurface structure is generally low probably due to the same mechanism proposed for negative SP anomalies associated with conductive mineral deposits (Sato and Mooney, 1960).

The general trend of SP at No. 2 in January shows an increase during production and decrease after shut-in. It can be interpreted as the positive charge is carried toward the well by the produced fluid that will be accumulated around the well during production. The decrease of production rate was caused the decline of the trend. After the shut-in, the trend changed to negative. The mechanisms of the negative response to the stepwise change of flow rate observed on January 27 th and fast increase and successive slow decrease after shut-in on January 27th are not defined yet. Further investigation is needed.

In July, SP at No. 2 decreased both after the start and shut-in of production. After the opening of the well, a sudden pressure drop is thought to induce a liquid-phase downflow within the two-phase zone, which can produce a negative SP on the surface (Ishido and Pritchett, 1999). During production, two opposite effects on SP exist; downward liquid- 


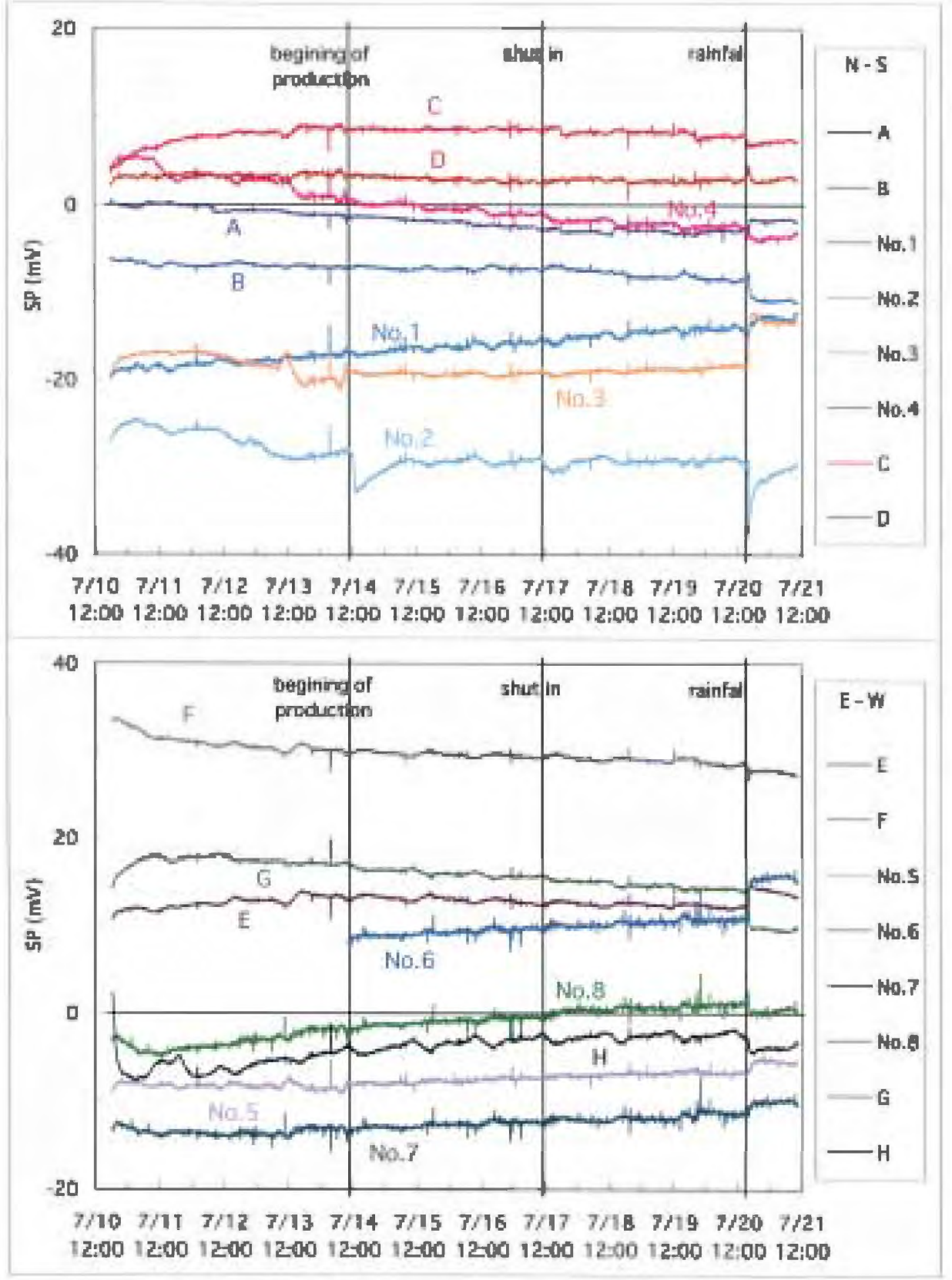

Fig. 8 "Relative" SP variations in July, 2001, after reducing external geomagnetic effects.

phase flow causes a SP decrease while the inflow toward the well causes a SP increase. By the balance of these two effects, SP at No. 2 recovers from the rapid drop and is maintained until shut-in. After shut-in, SP slightly decreases and shortly recovers though its mechanism is not identified yet. However it is considered that the change of the reservoir condition induced the different behavior after shut-in from that in January.

Although no quick SP response was observed at the other monitoring points in July, changes of SP trends corresponding to the well operations were detected at several points. It indicates that the change of fluid flow pattern in the reservoir was detected by SP monitoring. Monitoring points with SP trend changes only at the start of the production might have different hydrological characteristics from that with SP changes both at the start and end of production. Further investigation is necessary for the characterization of each monitoring point.

The effect of rainfall on SP was quite large in July while it was not identified in January. The difference comes from the dry and rainy seasons in Indonesia. In January when it rains almost everyday, the ground is already saturated with water everywhere. As a consequence, rainfalls give uniform vertical infiltration or surface run-off that doesn't give SP anomalies. However in the dry 
season such as in July, rainfalls into unsaturated ground causes an irregular infiltration, resulting in a SP anomaly.

Comparing the SP variation in January and July, the influence of external geomagnetic variation is considerably larger in July. It might be because of the seasonal or annual change of the magnitude of the telluric current (Maeda, 1982).

\section{Summary and conclusions}

Relative SP responses to short-term flow tests were monitored in January and July, 2000 around a wellsite in Mataloko, Indonesia. The flow test in January was conducted immediately after the well completion while that in July was after a threemonth long-term production test.

In January, the relative SP at all the eight monitoring points indicates sharp clear responses to the shut-in of the well. It is because the liquid-phase fluid in the reservoir is moved by a rapid pressure change.

In July, eight more monitoring points were added to extend the survey area. No quick response to the well operation was observed except for No. 2, which is located at the wellsite. However, changes in SP trend were observed at most of the monitoring points after the start of production. At some of these points, the recovery of the trend after shut-in was also observed.

Although the clear response to the well operation was observed both in January and July at No. 2, its behavior is quite different both for the long term and short term. It is considered that the change of the liquid phase saturation in the reservoir caused this difference.

Relative SP response to the well operation at each monitoring point corresponds to the characteristics of its hydrological settings. The different SP behaviors between January and July indicate the change of reservoir conditions caused by a long-term flowtest. The changes of the reservoir is detected by SP monitoring. Thus relative SP monitoring is a promising tool for both field exploration and monitoring.

Acknowledgements: The authors highly appreciate the fruitful discussion with Dr. T. Ishido about the reservoir behavior and SP variation. The authors also thank the colleagues and local people who made the SP monitoring at Mataloko possible.

\section{References}

Andan, A., Suhanto E., Sukirman, A., Ashari and Usmawardi (1997) Report on integrated geophysical investigation of Mataloko geothermal area, Ngada 2nd regency, Nusa Tenggara, Timur province. VSI Report.

Ishido, T. and Pritchett, J. W. (1999) Numerical simulation of electrokinetic potentials associated with subsurface fluid flow. J. Geophys. Res., 104, 15247-15259.

Maeda, H. (1982) Physics in Solar Planet Environment. Kyoritsu-shuppan, Tokyo (in Japanese).

Muraoka, H., Nasution, A., Urai, M., Takahashi, M. and Takashima, I. (2000) Regional geothermal geology of the Ngada district, Central Flores, Indonesia. Proceedings WGC 2000, 1473-1478.

Sato, M. and Mooney, H. M. (1960) The electronical mechanism of sulfide self-potentials. Geophysics, 25, 226-249.

Yasukawa, K., Andan, A., Kusuma. D. S. and Uchida, T. (1999) Self-potential survey in the Mataloko geothermal field, Flores, Indonesia. 1998 Interim Rept, Research Cooperation Project on the Exploration of Smallscale Geothermal Resources in the Eastern Part of Indonesia, Geol. Surv. Japan, 71-84.

Yasukawa, K., Andan, A. and Kikuchi, T. (2000) Self-potential survey in Nage and Mataloko geothermal fields, Flores, Indonesia. 1999 Interim Rept, Research Cooperation Project on the Exploration of Small-scale Geothermal Resources in the Eastern Part of Indonesia, Geol. Surv, Japan, 53-64.

Yasukawa, K., Suzuki, I. and Ishido, T. (2001) Reservoir monitoring by relative selfpotential observation at the Nigorikawa Basin, Hokkaido, Japan. Geothermal Resources Council Transactions, 25, 705-710.

Yokoi, K., Deguchi, T., Ide, T. and Tosha, T. (2001) Self-potential monitoring and its interpretation using numerical reservoir simulation at the Ogiri geothermal field, Japan. Geothermal Resources Council Transactions, 25, 711-715.

Received October 15, 2001

Accepted February 21, 2002 


\title{
インドネシアのヌサテンガラ州フローレス島マタロコ地熱地帯における 自然電位モニタリングによって確認された坑井操作に対する貯留層応答
}

安川香澄・Enar KUSDINAR・村岡洋文

\begin{abstract}
要 旨
インドネシアのヌサテンガラ州フローレス島マタロコにおいて, 坑井操作によって生じる貯留層内の 電位变化を検出する目的で, 自然電位 (SP) モニタリングを行った。噴気試験の期間にわたり，坑井周 辺の地表の SP 分布をモニタリングした。電位の基準点の問題を解決するため, 全測点での電位の平均 值を常にゼロと仮定した"相対" 自然電位の概念を取り入れた。その結果，貯留層状態に応じた相対自 然電位の変化がはっきりと観測された。このように, 相対自然電位モニタリングは, 貯留層範囲および その水理学的状態を把握に利用することができる.
\end{abstract}

